\title{
IMPLEMENTASI PENANGANAN PERTOLONGAN PERSALINAN OLEH BIDAN PADA MASA PANDEMI COVID-19 DAN ERA NEW NORMAL
}

\author{
Shinta Ika Sandhi , Desi Wijayanti Eko Dewi \\ Universitas Bhakti Kencana, Jl. Soekarno Hatta No. 99, (0294)381299 \\ Email: shinta.ika@bku.ac.id
}

\begin{abstract}
ABSTRAK
Indonesia sedang dalam situasi pandemi COVID-19 dan banyak pembatasan hampir ke semua layanan rutin termasuk pelayanan kesehatan maternal dan neonatal, hal ini mempengaruhi jumlah kunjungan ibu hamil, adanya anjuran menunda pemeriksaan kehamilan dan kelas ibu hamil, serta adanya ketidaksiapan layanan dari segi tenaga dan sarana prasarana. Pada masa pandemi Covid-19, 62,7 \% persalinan ditolong oleh bidan sehingga bidan diharapkan mampu memberikan pelayan yang baik sekaligus melakukan proteksi diri agar tidak tertular. Tujuan penelitian ini mengetahui implementasi penanganan pertolongan persalinan oleh bidan pada masa pandemi Covid-19 dan era new normal dilihat dari karakteristik, prosedur pertolongan persalinan, proses pertolongan persalinan dan kendala dalam pertolongan persalinan. Penelitian ini merupakan penelitian deskriptif kualitatif menggunakan analisa pendekatan studi kasus. Penentuan sample dilakukan secara purposive sampling. Informan berjumlah 5 orang bidan yang bekerja di puskesmas PONED. Pengumpulan data dengan cara wawancara mendalam. Hasil Penelitian ini didapatkan bahwa implementasi pertolongan persalinan yang dilakukan bidan dimasa pandemi Covid-19 dan era new normal sudah sesuai dengan aturan pelayanan puskesmas pada masa pandemi Covid-19. Adapun beberapa kendala yang dihadapi bidan diantaranya penggunaan APD level 3, keadaan ruang yang tidak ada sirkulasi udara dan sulitnya rumah sakit rujukan untuk ibu bersalin dengan hasil swab postif Covid-19.
\end{abstract}

Kata Kunci : implementasi; persalinan; bidan; Covid-19

\section{IMPLEMENTATION OF DELIVERY HANDLING BY MIDWIFE DURING THE COVID-19 PANDEMIC AND THE NEW NORMAL}

\begin{abstract}
Indonesia is currently in a COVID-19 pandemic situation and there are many restrictions on almost all routine services including maternal and neonatal health services, this affects the number of visits by pregnant women, there are recommendations for postponing pregnancy check-ups and classes for pregnant women, as well as the unpreparedness of services in terms of personnel, facilities and infrastructure. During the COVID-19 pandemic, $62.7 \%$ of deliveries were assisted by midwives so that midwives were expected to be able to provide good service and at the same time protect themselves from being infected. The purpose of this study was to determine the implementation of Delivery Handling of Childbirth by Midwives during the Covid-19 Pandemic Period and the New Normal Era seen from the characteristics, delivery assistance procedures, delivery assistance processes and obstacles in delivery assistance. This research was a descriptive qualitative research using case study approach analysis. Determination of the sample is done by purposive sampling. The informants were 5 midwives who worked at the Basic Emergency Neonatal Obstetric Service Training health center. Data collection was obtained by in-depth interviews. The results of this study found that the implementation of delivery assistance carried out by midwives during the Covid-19 pandemic and the new normal era was in accordance with the rules of health center services during the Covid-19 pandemic. There were several obstacles faced by midwives including the use of level 3 PPE (personal protective equipment), room conditions that had no air circulation and the difficulty of referral hospitals for maternity mothers with positive COVID-19 swab results.
\end{abstract}

Keywords: implementation; childbirth; midwife; Covid-19 


\section{LATAR BELAKANG}

Program peningkatan cakupan pelayanan kesehatan ibu adalah suatu program yang dicanangkan dalam upaya mempercepat penurunan $\mathrm{AKI}$ dengan cara memberikan pelayanan $\mathrm{ANC}$, perencanaan $\mathrm{KB}$, pertolongan persalinan dan pelayanan nifas yang merupakan "upaya terobosan" dalam percepatan penurunan angka kematian ibu dan bayi baru lahir melalui kegiatan peningkatan akses dan kualitas pelayanan yang sekaligus merupakan kegiatan yang membangun potensi masyarakat, khususnya kepedulian masyarakat untuk persiapan dan tindakan dalam menyelamatkan ibu dan bayi baru lahir. ${ }^{1}$ (Artathi Eka Suryandari and Trisnawati 2020)

Sampai saat ini, pengetahuan tentang infeksi COVID-19 dalam hubungannya dengan kehamilan dan janin masih terbatas dan belum ada rekomendasi spesifik untuk penanganan ibu hamil dengan COVID-19. Berdasarkan data yang terbatas tersebut dan beberapa contoh kasus pada penanganan Coronavirus sebelumnya dan beberapa kasus COVID-19, dipercaya bahwa ibu hamil memiliki risiko lebih tinggi untuk terjadinya penyakit berat, morbiditas dan mortalitas dibandingkan dengan populasi umum.(Direktorat Kesehatan Keluarga 2020).

Sebagian besar pemeriksaan kehamilan dilakukan oleh bidan $(82,4 \%)$ bertempat di Bidan Praktek Swasta (41\%) sedangkan proporsi persalinan dengan kualifikasi tertinggi pada perempuan umur 10-54 tahun paling banyak di tolong oleh bidan yaitu 62,7\% (Ellyvon Pranita 2020). Kematian ibu dan kematian neonatal di Indonesia masih menjadi tantangan besar, apalagi pada saat situasi bencana. Pada Tahun 2019 kematian bayi baru lahir di Kabupaten Kendal, Jawa Tengah terbukukan 119 kasus. Oleh karena itu, Kendal menganggap penting optimalisasi fungsi bidan dalam pelayanan kesehatan ibu hamil dan bayi.

Indonesia sedang menghadapi bencana nasional non alam COVID-19 sehingga pelayanan kesehatan maternal dan neonatal menjadi salah satu layanan yang terkena dampak baik secara akses maupun kualitas. Dikhawatirkan, hal ini menyebabkan adanya peningkatan morbiditas dan mortalitas ibu dan bayi baru lahir. Dalam situasi pandemi COVID19 ini, banyak pembatasan hampir ke semua layanan rutin termasuk pelayanan kesehatan maternal dan neonatal. Seperti ibu hamil menjadi enggan ke puskesmas atau fasiltas pelayanan kesehatan lainnya karena takut tertular, adanya anjuran menunda pemeriksaan kehamilan dan kelas ibu hamil, serta adanya ketidaksiapan layanan dari segi tenaga dan sarana prasarana termasuk Alat Pelindung Diri.(Gugus Tugas Percepatan Penanganan COVID-19 2020a)

Perkumpulan Obstetri Ginekologi Indonesia (POGI) mengeluarkan sejumlah rekomendasi dalam penanganan ibu hamil dan ibu bersalin untuk untuk mencegah penularan Covid-19 pada ibu, bayi, dan tenaga kesehatan. POGI meminta semua persalinan harus dilakukan di fasilitas kesehatan (faskes) seperti puskesmas, bidan, dan rumah sakit, selama wabah Covid-19. Tujuan utama persalinan harus di faskes adalah untuk menurunkan risiko penularan terhadap tenaga kesehatan serta mencegah morbiditas dan mortalitas maternal. Apalagi, 13,7\% ibu hamil tanpa gejala bisa menunjukkan hasil positif Covid-19 dengan pemeriksaan polymerase chain reaction (PCR). Oleh karena itu, penolong persalinan harus menggunakan alat pelindung diri (APD) minimal sesuai level 2.(Kemenkes RI 2020a).

Virus Corona ini pada awalnya lebih banyak menyerang kelompok usia lanjut, namun belakangan ini sudah menginfeksi di seluruh kelompok usia, mulai dari usia produktif, remaja, balita, bayi, tidak terkecuali kelompok ibu hamil. Di kabupaten Kendal angka penderita Covid-19 terkonfirmasi sebesar 9.565 orang yang 10\%nya penderitanya adalah ibu hamil. Studi pendahuluan yang dilakukan dengan melakukan wawancara pada 5 ibu hamil didapatkan adanya kecemasan pada situasi pandemi Covid-19, mereka harus mengkhawatirkan keadaan bayinya saat persalinan dan mereka juga takut apabila saat dilakukan pemeriksaan swab hasilnya positif karena akan langsung dilakukan rujukan ke rumah sakit. 
Selama pandemi COVID-19 dan menghadapi era New Normal, pelayanan kesehatan harus tetap berjalan secara optimal, aman bagi pasien dan bidan dengan berbagai penyesuaian berdasarkan panduan penanganan covid atau protokol kesehatan. Panduan pertolongan persalinan oleh bidan pada masa pandemi Covid-19 sudah ditetapkan dan diharapkan semua bidan dalam memberikan pelayanan kebidanan khususnya persalinan dapat dipatuhi guna menghindari penularan Covid-19. Ketakutan masyarakat akan tertularnya Covid-19 di layanan kesehatan juga memberikan kontribusi yang besar dalam pemberian layanan kebidanan secara langsung. Tujuan penelitian ini untuk mengetahui implementasi penanganan pertolongan persalinan oleh bidan pada masa pandemi Covid-19 dan era new normal di Kabupaten Kendal.

\section{METODE}

Penelitian ini menggunakan desain kualitatif yaitu prosedur penelitian yang menghasilkan data deskriptif berupa kata-kata tertulis atau lisan dari orang-orang dan perilaku yang dapat diamati.(Lexy J. Moleong 2019). Rancangan penelitian menggunakan studi kasus, pendekatan studi kasus ini merupakan jenis pendekatan yang digunakan untuk menyelidiki dan memahami sebuah kejadian atau masalah yang telah terjadi dengan mengumpulkan berbagai macam informasi yang kemudian diolah untuk mendapatkan sebuah solusi agar masalah yang diungkap dapat terselesaikan.

Pengumpulan data dilakukan melalui wawancara mendalam dengan alat bantu perekam suara yaitu handphone catatan lapangan. Data dikumpulkan melalui teknik observasi, indepth interview, wawancara dan dokumentasi. Data yang telah terkumpul kemudian diikuti tahapan reduksi, penyajian data dan penyimpulan data. Uji validitas dilakukan dengan cara triangulasi sumber. Reliabilitas dilakukan dengan cara auditing data. Setiap data atau informasi yang diperoleh dianalisis secara terinci dan dikelompokkan sesuai dengan topik penelitian. Uji validitas dilakukan kepada Kepala Puskesmas.

\section{HASIL}

Hasil penelitian ini menguraikan temuan penelitian pada implementasi pertolongan persalinan di masa pandemi Covid-19 dan era new normal. Permasalahan penelitian ini mendiskripsikan berdasarkan aspek karakteristik, prosedur pertolongan persalinan, proses pertolongan persalinan dan kendala dalam pertolongan persalinan di masa pandemi covid dan era new normal

\section{Karakteristik Informan}

Tabel 1 Karakteristik Responden

\begin{tabular}{|c|c|c|c|}
\hline Informan & Usia & Pendidikan & Masa Kerja \\
\hline 1 & 52 th & $\begin{array}{c}\text { DIV } \\
\text { kebidanan }\end{array}$ & 33 th \\
\hline 2 & 53 th & $\begin{array}{c}\text { DIV } \\
\text { kebidanan }\end{array}$ & 39 th \\
\hline 3 & 54 th & $\begin{array}{c}\text { DIV } \\
\text { kebidanan }\end{array}$ & 30 th \\
\hline 4 & 52 th & $\begin{array}{c}\text { DIV } \\
\text { kebidanan }\end{array}$ & 32 th \\
\hline 5 & 51 th & $\begin{array}{c}\text { DIV } \\
\text { kebidanan }\end{array}$ & 32 th \\
\hline
\end{tabular}

Tabel 1 menunjukkan karakteristik responden dilihat dari usia, pendidikan terakhir dan masa kerja. Sesuai dengan tabel maka seluruh responden berusia lebih dari 50 tahun dan berpendidikan DIV kebidanan. Masa kerja responden lebih dari 30 tahun.

\section{Implementasi Pertolongan Persalinan oleh bidan dimasa pandemi Covid-19 dan era new normal}

\section{Bagan 1. Kebijakan Pertolongan persalinan di masa pandemi Covid-19 dan era new normal}

....lya bu ada, kalau ditandatangani malah belum bu, Cuma sudah di acc. Dan kita sudah jalan menggunakan SOP itu (P1)

..... SOP ada bu yang baru terkait pandemi ini, Cuma belum di sahkan, namun kita jalan dulu sesuai SOP dan petunjuk teknis dari Dinkes"(P2)

....."Penanganan persalinan di era pandemi ini otomatis pasti ada perbedaan dari awal kita mulai penerimaan pasien baru itu kita sudah kita sudah menerapkan standar operasional ya untuk penanganan pasien di era pandemi sesuai dengan SOP kita"(P3)

.....Ada bu, SOP baru dan sudah disosialisasikan. 
Sosialisasi lewat lokmin atau rapat-rapat. Selalu kami diingatkan untuk proses pencegahan penularan Covid19. (P4)

....."saat pandemi covid ada perubahan besar di SOP pastinya, sudah ada disahkan dan disosialisasikan kok"(P5)

\section{Bagan 2. Prosedur Pertolongan persalinan di Puskesmas pada masa pandemi Covid-19 dan era new normal}

.... " perbedaannya di penerimaan pasien, kita pastikan ibu membawa surat keterangan bebas Covid dari puskesmas"(P1)

....."Pasien harus dinyatakan negative covid dengan membawa surat keterangan. Peemriksaannya dengan PCR 1 minggu sebelum HPL. Kalau hanya rapid antibodi rapid antigen itu itu belum e memastikan untuk kita mengetahui bahwa dia itu terpapar covid atau bukan. Makanya kita memakai yang PCR. Penunggu ya di skrining, pasien juga harus diskrinning, harus seperti itu. Berarti dua-duanya nanti misalkan negatif atau positif kita sudah tahu. Penunggu harus di ruangan selama menunggu si istri melahirkan, tidak boleh kemana-mana kalau dia butuh apa-apa telepon keluarga. Misalkan butuh foto copy kk, ktp, butuh syarat, butuh e kebutuhan apapun harus telepon keluarga"(P2)

....."begitu pasien itu datang kalau kita di era pandemi itu tentunya pasien juga akan dilakukan skrining, kemudian juga akan dilakukan pemeriksaan antigen, karena itu memang sudah menjadi standar nya seperti itu. kalau memang Pasien itu datang itu pasien sudah dilakukan skrining akan tetapi jatuh temponya sudah lebih dari 5 hari karena memang aturan dari dinas kemarin itu h-3 itu harus sudah dilakukan skrining ini yang dilaksanakan massal sesuai dengan HPLnya Walaupun hasilnya entah negatif tapikan hasilnya masih abu-abu nih. Nah kita untuk waspada aja. Katakanlah ketika pasien dateng dia belum melakukan pemeriksaan antigen kita anhgap itu pasien abu-abu. Sehingga amannya ya kita masukan ke isolasi"(P3)

....."Pasien yang datang itu kalau dulu sebelum pandemi covid ini pasien yang datang ke UGD, poned, itu kita langsung memasukkan Pasien itu ke ruang VK ruang tindakan di poned, nggih. Ada perbedaannya pada saat covid ini kita harus mengadakan, e pasien yang datang itu kita harus mengadakan skrining dulu" (P4)

....."begitupun dengan ibu hamil yang akan bersalin, harus dipastikan sudah melakukan cek PCR. Dan itu menjadi tanggung jawab bidan wilayahnya untuk memastikan ibu yang akan bersalin $\mathrm{H}-7$ sudah melakukan tes PCR, karna itu gratis. Missal sampai dengan HPL kok hasil PCR nya sudah kelewat maka diminta untuk tes ulang dengan biaya sendiri.(P5)

\section{Bagan 3. Proses pertolongan persalinan di masa pandemi Covid-19 dan era new normal}

.... "pertolongan persalianan dilakukan di bed khusus yaitu yang ada delivery climber nya, pasien dan penunggu juga harus menggunakan masker selama persalinan, tidak ada IMD pada pasien yang harus masuk ruang isolasi. Bidan harus siap menggunakan APD lengkap level 3 pada persalinaan di ruang isolasi" (P1)

....."proses pertolongan persalinan masih sama sih, Cuma bedanya lebih ribet saat penggunaan APD. Missal itu ada diruang isolasi harus pakai APD level 3. Pendamping boleh masuk tapi harus negative juga hasil pemeriksaan PCR nya. Pasien hanya diobesrvasi selama 6 jam kemudian di pulangkan"(P2)

....." bedanya paling kalau pasien di ruang isolasi tidak boleh ada yang mendampingi. Kalo IMD juga tidak boleh. Pasien boleh pulang saat semua sudah selsai kalo sudah 6 jam dan ruangan segera di desinfektan" (P3) ....."ada bedanya di langkah APN kalau pada kasus yang ibu masuk ke ruang isolasi tidak dilakukan IMD bu.(P4)

....." penggunaan APD level 3 pada kasus ibu hamil yang positif atau yang masih dinyatakan ragu2"(P5)

\section{Bagan 4. Kendala dalam Pelayanan di masa pandemi Covid-19 dan era new normal}

....."pasti ada, missal saat akan menjahit perineum dengan kita menggunakan APD level 3 sedikit menyusahkan, selain itu kan gak boleh di setel $A C$ nya"(P1)

...." Kendalanya Kita pakai level 3, stres kita harus 4 tangan di ruang isolasi, terus mitra yang satu di luar. Jadi saya pun tidak boleh keluar-keluar, di dalem terus "(P2)

....."Pakai APD memang sumuk, karena kita gaboleh ac gaboleh kipas. lya tho? Dengan pakaian yang begitu sangat luar biasa kadang-kadang Setelah itu mereka kelelahan nggih, kayak mandi keringat. Selain itu Ketika kami saat itu sangat-sangat kerepotan untuk melakukan rujukan ke rumah sakit sekarang belum tentu langsung ke jawab sekarang bisa siang nanti bisa sore nanti atau bisa malam nanti sementara Pasien itu pun tetep proses perjalanan ini kan tetep proses pembukaan ini tetap berjalan terus"(P3)

....."Kalau kendala dari penolong paling saat pakai APD level 3 dan kalau sudah masuk ke ruangan isolasi tidak boleh keluar. Selain itu kalau lama mencari rumahsakit rujukan, itu juga jadi kendala juga"(P4)

....."kendala jelas ada, apalagi kalau pasien yang belum swab, nah itu kita harus prepare buat segera melakukan tes lagi, kendala lain paling saat rujukan kita harus berpacu juga dengan waktu, karena yang datang ke puskesmas biasanya ibu bersalin yang sudah masa aktif dan mencari rumah sakit rujukan juga susah"(P5) 


\section{PEMBAHASAN}

\section{Karakteristik Informan}

Informan utama adalah bidan PONED di lima puskesmas, seluruh informan utama adalah orangorang yang berpengalaman dalam tugas sebagai tenaga kesehatan, khususnya memberikan pelayanan kebidanan terhadap ibu dan anak. Seluruh informan utama sudah mempunyai kompetensi pelayanan sesuai dengan standar pelayanan kebidanan termasuk dalam memberikan pelayanan pertolongan persalinan.

Karakteristik informan pada penelitian ini adalah sebagian besar berusia lebih dari 50 tahun dan masa kerja lebih dari 10 tahun dengan pendidikan DIV Kebidanan. Usia yang lebih tua cenderung memiliki kualitas pelayanan proses persalinan yang lebih baik dibandingkan dengan usia yang lebih muda, hal ini mendukung teori bahwa produktifitas karyawan yang sudah lama bekerja di sebuah instansi artinya sudah bertambah usia, bisa mengalami peningkatan karena pengalaman, dan lebih bijaksana dalam pengambilan keputusan. Hal sama juga dengan masa kerja yang berkaitan erat dengan pengalamanpengalaman yang didapat selama dalam menjalankan tugas. Karyawan yang berpengalaman dipandang lebih mampu dalam melaksanakan tugas. Makin lama kerja seseorang kecakapan mereka akan lebih baik karena sudah dapat menyesuaikan diri dengan lingkungan pekerjaan. Sejalan dengan penelitian Wahyuni 2018 bahwa terdapat hubungan yang bermakna antara lama masa kerja dengan kualitas pelayanan persalinan (Wahyuni, 2018).

Masa kerja yang lama memperlihatkan bahwa bidan yang menangani kasus-kasus pesalinan baik yang normal maupun yang tidak normal sudah cukup berpengalaman. Hal ini berkaitan pula pada pengambilan keputusan. Keputusan yang cepat seringkali dihadapkan pada keadaan persalinan di masa pandemi Covid-19. Seperti contoh pada ibu bersalin yang positif maka harus dilakukan rujukan yang sebelumnya juga dipastikan apakah ibu bersalin tersebut dapat segera mendapatkan penanganan apabila ternyata rumah sakit rujukannya penuh.

Pelayanan di fasilitas kesehatan perlu diperhatikan kesiapan tenaga kesehatan yaitu Tenaga kesehatan di RS, Puskesmas dan Praktik Mandiri, Bidan Desa dan kader kesehatan di dalam wilayah kerja memiliki pengetahuan tentang penularan COVID-19, serta pengetahuan tentang tanda bahaya dan gejala kegawatdaruratan ibu dan bayi baru lahir selain itu Tenaga kesehatan memahami algoritma tata laksana ibu hamil/ibu bersalin/bayi baru lahir dengan komplikasi atau kegawat daruratan serta alur pelayanan kesehatan ibu dan bayi dalam situasi pandemi COVID-19.

Tenaga kesehatan memahami indikasi, pemakaian, melepaskan dan membuang Alat Pelindung Diri yang dipakai serta mematuhi penggunaannya dengan benar sesuai tugas di masing-masing area dan Tenaga Kesehatan mampu memberikan edukasi kepada keluarga dan masyarakat agar mendukung lbu hamil, Ibu bersalin, Ibu menyusui dan pengasuh memahami penggunaan masker dan etika batuk, menjaga kebersihan diri dan lingkungan di rumah dan ketika berkunjung ke fasyankes, dan menyampaikan status Orang Dalam Pemantauan (ODP), Pasien Dalam Pengawasan (PDP) atau terkonfirmasi positif COVID-19.(Gugus Tugas Percepatan Penanganan COVID-19 2020)

\section{Pedoman dan Kebijakan Pertolongan persalinan di masa pandemi Covid-19 dan era new normal.}

Kementerian Kesehatan telah menerbitkan pedoman untuk penanganan ibu hamil, melahirkan, dan nifas serta bayi yang baru lahir pada masa pandemi. Pedoman ini diperuntukkan bagi tenaga kesehatan, ibu hamil, dan keluarganya. Harapannya adalah baik ibu maupun bayi bisa tetap memperoleh pelayanan esensial.(Kemenkes RI 2020a)

Ada perubahan kebijakan berupa standar operasional prosedur di setiap puskesmas PONED terkait adanya pandemi Covid-19. Hal ini sesuai dengan yang disampaiakan seluruh informan pada bagan 1. Kebijakan tersebut 
disesuaikan dengan Petunjuk Teknis Pelayanan Puskesmas Pada Masa Pandemi COVID-19. Petunjuk teknis ini disusun sebagai acuan bagi seluruh petugas Puskesmas dalam melaksanakan tugas dan fungsinya pada situasi pandemi COVID-19. Pembinaan dan pendampingan oleh Dinas Kesehatan Kabupaten/Kota secara terencana, terpadu, berkala dan berkesinambungan akan sangat membantu Puskesmas dalam menjalankan fungsinya selama pandemi Covid-19.

Penerapan SOP yang baik menghasilkan kelancaran aktivitas operasional organisasi, kepuasaan pelanggan/masyarakat, serta menjaga nama baik dan kualitas suatu lembaga pelayanan. Apabila semua kegiatan sudah sesuai dengan yang ditetapkan dalam Standar Operasional Prosedur, maka secara bertahap kualitas pelayanan publik akan lebih profesional, cepat dan mudah. Penerapan SOP juga berkaitan dengan mutu. Hal ini sejalan dengan penelitian Hikma (2014) yaitu Ada hubungan antara mutu pelayanan persalinan oleh bidan desa dengan kepuasan ibu bersalin.(Hikma, Kartasura, and Mawarni 2014)

Pandemi COVID-19 merupakan situasi yang terjadi secara mendadak dan cepat. Kondisi ini tentu sangat berpengaruh kepada perencanaan yang telah disusun oleh Puskesmas. Oleh karena itu, Puskesmas perlu menyesuaikan tahapan manajemen Puskesmas yang telah disusun dan direncanakan sebelumnya dengan kebutuhan pelayanan dalam menghadapi pandemi COVID-19. Pelaksanaan revisi sesuai kebutuhan pandemi COVID-19 mengacu pada juknis/ pedoman yang berlaku melalui pembinaan dan koordinasi dengan dinas kesehatan daerah kabupaten/kota. (Kemenkes RI 2020b)

Buku Petunjuk Teknis Pelayanan Puskesmas pada Masa Pandemi COVID-19 ini disusun dengan maksud memberikan acuan bagaimana Puskesmas melakukan penyesuaian-penyesuaian yang diperlukan dalam manajemen maupun penyelenggaraan pelayanannya. Penyesuaian tersebut perlu dilakukan untuk merespon dampak yang terjadi akibat COVID-19 sekaligus mencegah penularan pada saat penyelenggaraan pelayanan. (Kemenkes RI 2020b)

Hasil wawancara yang telah dilakukan sebagian besar SOP mengenai pelayanan persalinan sudah disusun dan di sahkan. Adapun puskesmas yang belum mengesahkan SOP, pelaksanaan prosedur pelayanan tetap dilakukan sesuai dengan petunjuk teknis pelayanan puskesmas pada masa pandemi Covid-19.

Adapun perbedaan kebijkaan yaitu Persalinan normal tetap dapat dilakukan di Puskesmas bagi ibu hamil dengan status BUKAN ODP, PDP atau terkonfirmasi COVID19 sesuai kondisi kebidanan dan Ibu hamil berisiko atau berstatus ODP, PDP atau terkonfirmasi COVID-19 dilakukan rujukan secara terencana untuk bersalin di fasyankes rujukan. Hal ini sesuai dengan pernyataan triangulasi yang dilakukan dengan kepala puskesmas dimana dalam menyusun SOP dimasing-masing puskesmas merujuk pada petunjuk teknis pelayanan puskesmas pada masa pandemi Covid-19.

Pada pelaksanaan Lokmin bulanan di situasi saat ini, tidak hanya membahas terkait kegiatan yang sudah dan akan dilaksanakan, melainkan Puskesmas perlu membahas bersama pedoman terkait pelayanan pada masa pandemi COVID-19. Hal ini perlu dilakukan mengingat banyak pedoman program yang disesuikan dengan kondisi pandemi COVID-19 dimana penyusunan/terbitnya juga hampir bersamaan. Untuk mengantisipasi tersebut dan agar petugas di Puskesmas dapat dengan cepat mengikuti perkembangan, maka kepala Puskesmas menugaskan kepada koordinator program untuk mempelajari pedoman-pedoman tersebut dan selanjutnya petugas tersebut akan menjelaskan secara bergantian kepada seluruh petugas lainnya dalam forum Lokmin bulanan (Kemenkes RI 2020)

\section{Prosedur Pertolongan persalinan di Puskesmas pada masa pandemi Covid-19 dan era new normal}

Fasilitas pelayanan kesehatan mulai dari tingkat primer sampai rujukan termasuk Klinik masih merupakan harapan masyarakat dalam 
menangani COVID-19 serta masalah kesehatan lainya. Dalam memasuki adaptasi kebiasaan baru, seluruh fasilitas pelayanan kesehatan harus mempersiapkan semua sumber daya yang dimiliki. Standar Operasional Prosedur (SOP) pelayanan kesehatan yang akan dilaksanakan harus disesuaikan dengan memperhatikan keselamatan tenaga kesehatan dan masyarakat penerima pelayanan agar terhindar dari penularan COVID-19 (Kementerian Kesehatan RI. Direktorat Jenderal Pelayanan Kesehatan 2020) Persalinan normal tetap dapat dilakukan di Puskesmas bagi ibu hamil dengan status bukan ODP, PDP atau terkonfirmasi COVID-19 sesuai kondisi kebidanan. (Kemenkes RI 2020a)

Pada trimester ketiga kehamilan, banyak rangkaian pemeriksaan yang harus dijalani ibu hamil. Hal ini untuk mempersiapkan persalinan agar berjalan lancar. Namun di masa pandemi seperti ini, pemeriksaan sebelum bersalin berbeda dengan sebelumnya. Ada beberapa pemeriksaan tambahan untuk memastikan persalinan di masa pandemi tetap aman untuk ibu dan bayi.(Ellyvon Pranita 2020) Pada saat menjelang persalinan, ibu hamil akan melalui proses pemeriksaan tambahan yaitu pemeriksaan screening Covid-19.

Sesuai bagan 3. Seluruh informan menyatakan seluruh ibu hamil yang akan melahirkan di puskesmas wajib melakukan screaning covid dengan sebelumya melakukan tes PCR ataupun tes antigen $\mathrm{H}-3$ sampai dengan $\mathrm{H}-7$ sebelum HPL.

Prosedur penanganan persalinan di puskesmas pada ibu hamil dengan hasil swab negative dilakukan di ruang perslainan/VK. Sedangkan pada ibu hamil yang belum melakukan swab dan terkonfirmasi covid maka segera dilakukan rujukan dengan sebelumnya bidan PONED berkoordiansi dengan kepala puskesmas untuk mencari rumah sakit rujukan. Namun apabila pasien datang saat kala aktif dan tidak memungkinkan untuk dilakukan rujukan maka pertolongan persalinaan dilakukan di ruang isolasi yang disediakan puskesmas dengan memperhatikan pencegahan penularan Covid-19 antara pasien dan bidan.

Hal yang sama disampaikan oleh kepala puskesmas sebagai triangulasi, dimana bidan desa bertanggung jawab atas sosialisasi dan pendataan ibu hamil yang mendekati hari perkiraan lahir untuk melakukan screanging Covid-19 secara gratis di puskesmas sesuai dengan jadwal screaning. Screaning dilakukan di puskesmas secara gratis kepada ibu hamil yang mendekati hari perkiraan lahir.

Proses pertolongan persalinan di masa pandemi Covid-19 dan era new normal

Persalinan normal menurut WHO (2010) adalah persalinan yang dimulai secara spontan, berisiko rendah pada awal persalinan dan tetap demikian selama proses persalinan, bayi lahir secara spontan dalam presentasi belakang kepala pada usia kehamilan 37-42 lengkap dan setelah persalinan ibu maupun bayi berada dalam kondisi sehat.(Oktarina 2016)

Sesuai dengan pernyataan sebagian besar dari responden dapat disimpulkan bahwa pada saat pandemi Covid-19 dan era new normal, penatalaksanaan pertolongan persalinan pada ibu hamil dengan hasil Swab negative Covid-19 di puskesmas dilakukan dengan 60 langkah asuhan persalinan normal pada saat pencegahan infeksi bidan mengenakan APD level 2. Sedangkan ibu hamil yang masuk dalam ruang isolasi maka pertolongan persalinan dilakukan oleh bidan dengan menggunakan APD level 3 dan tidak dilakukan inisiasi menyusu dini (IMD). Risiko utama untuk bayi menyusui adalah kontak dekat dengan ibu yang cenderung terjadi penularan melaui droplet infeksius di udara. (PP POGI 2020)

Pemakaian APD secara lengkap untuk melindungi bidan dari paparan virus Covid-19 pada saat pertolongan persalinan sangatlah penting, mengingat pasien bisa saja menderita Covid-19 tanpa gejala atau Orang Tanpa Gejala (OTG). Hal ini sesuai dengan penelitian yang dilakukan London et al pada tahun 2020 di New York menyebutkan bahwa pasien bersalin terkonfirmasi Covid-19 berisiko lebih 
besar mengalami persalinan preterm dan membutuhkan bantuan pernafasan dengan $\rho$ value 0,007 dan 0,01 (Artathi Eka Suryandari and Trisnawati 2020)

Pendampingan yang dilakukan suami atau keluarga ibu pada masa pandemi Covid19 dan era new normal masih boleh dilakukan dengan syarat pendamping persalinan harus melakukan swab dan dinyatakan negative. Pendamping persalinan yang dapat masuk ke ruang persalinan hanya satu orang dan tidak di perkenankan untuk keluar masuk ruangan. Hal tersebut sesuai dengan petunjuk teknis pelayanan kesehatan di klinik yaitu Hanya pasien lansia atau yang perlu pendampingan saja seperti kasus gawat darurat, persalinan yang diperbolehkan membawa satu pendamping pasien(Kementerian Kesehatan RI. Direktorat Jenderal Pelayanan Kesehatan 2020)

\section{Kendala dalam Pelayanan masa pandemi Covid-19 dan era new normal}

Sebagian besar Informan mengutarakan bahwa beberapa kendala dialami bidan dalam pertolongan persalinan di masa pandemi Covid-19 diantaranya penggunaan APD level 3 pada isaat menolong persalinan pada ibu hamil di ruang isolasi. Keadaan ruang yang tidak ada sirkulasi udara membuat bidan harus menahan suhu panas saat menolong persalianan.

Kendala yang dihadapi ibu bersalian yang diisampaiakan oleh ibu bersalin di puskesmas adalah penggunaan masker pada saat persalinan. Hal ini tetap harus dilakukan untuk mencegah penularan Covid-19. Prinsipprinsip pencegahan COVID-19 pada ibu hamil, bersalin, nifas dan bayi baru lahir di masyarakat meliputi universal precaution dengan selalu cuci tangan memakai sabun selama 20 detik atau hand sanitizer, pemakaian alat pelindung diri, menjaga kondisi tubuh dengan rajin olah raga dan istirahat cukup, makan dengan gizi yang seimbang, dan mempraktikan etika batuk-bersin. (Direktorat Kesehatan Keluarga 2020)

Kendala lain yang dihadapi adalah pencarian rumah sakit rujukan untuk ibu bersalin dengan hasil swab postif Covid-19. Sehingga muncul inisiatif dari puskesmas
PONED untuk menyediakan ruang isolasi apabila pada saat datang untuk melahirkan ibu tidak memungkinkan untuk dirujuk. Hal ini sesuai yang disampaikan oleh triangulasi, penyediaan ruang isolasi diharapkan dapat membantu meringankan kecemasan ibu dalam proses persalinan.

\section{KESIMPULAN DAN SARAN}

Implementasi pertolongan persalinan oleh bidan pada masa pandemi Covid-19 dan era new normal sudah sesuai dengan Petunjuk Teknis Pelayanan Puskesmas Pada Masa Pandemi COVID-19 seperti sudah adanya perubahan dan sosialaisai SOP dan kebijakan mengenai pertolongan persalinan namun bukti fisik dokumen belum semua puskesmas PONED ada. Prosedur pertolongan persalinan di Puskesmas pada masa pandemi Covid-19 dan era new normal yaitu ibu hamil yang akan melahirkan di puskesmas wajib melakukan screaning covid dengan sebelumya melakukan tes PCR ataupun tes antigen $\mathrm{H}-3$ sampai dengan $\mathrm{H}-7$ sebelum $\mathrm{HPL}$. Penggunaan level APD dan penggunaan masker pada ibu bersalin serta pendamping persalinan yang dipastikan melakukan swab PCR dengan hasil negative.

Adapun kendala yang dihadapi bidan dalam pertolongan persalinan penggunaan APD level 3, keadaan ruang yang tidak ada sirkulasi udara dan sulitnya rumah sakit rujukan untuk ibu bersalin dengan hasil swab postif Covid-19 sehingga harus siap ditolong di puskesmas.

Saran untuk Penelitian selanjutnya lebih kearah bagaiamana implementasi pelaksanaan persalinan setelah pasien di rujuk ke rumah sakit rujukan pada ibu dengan kasus Covid-19.

\section{REFERENSI}

Artathi Eka Suryandari, and Yuli Trisnawati. 2020. "Studi Deskriptif Perilaku Bidan Dalam Penggunaan Apd Saat Pertolongan Persalinan Selama Pandemi Covid-19." Jurnal Bina Cipta Husada.

Direktorat Kesehatan Keluarga. 2020. "Pedoman Bagi Ibu Hamil, Ibu Nifas, Dan Bayi Baru Lahir Di Era 
Pandemi Covid-19." Kementrian Kesehatan RI.

Ellyvon Pranita. 2020. "Melahirkan Di Masa Pandemi? Ini Pemeriksaan Tambahan Untuk Ibu Hamil"." Kompas.com.

https://www.kompas.com/sains/read/2020/06/25/0 70200323/melahirkan-di-masa-pandemi-inipemeriksaan-tambahan-untuk-ibu-hamil?page=all.

Gugus Tugas Percepatan Penanganan COVID-19. 2020a. "Protokol Petunjuk Praktis Layanan Kesehatan Ibu Dan Bayi Baru Lahir Selama Pandemi COVID-19." Protokol Gugus Tugas Percepatan Penanganan Covid-19 Ri 4(April): 111. https://covid19.go.id/p/protokol/protokol-b-4petunjuk-praktis-layanan-kesehatan-ibu-dan-bblpada-masa-pandemi-Covid-19.

Gugus Tugas Percepatan Penanganan COVID-19. 2020b. "Protokol Petunjuk Praktis Layanan Kesehatan Ibu Dan Bayi Baru Lahir Selama Pandemi COVID-19." Protokol Gugus Tugas Percepatan Penanganan Covid-19 Ri.

Hikma, Martha Irene Kartasura, and Atik Mawarni. 2014. "Hubungan Mutu Pelayanan Persalinan Normal Oleh Bidan Desa Dengan Kepuasan Ibu Bersalin Di Kabupaten Luwu Sulawesi Selatan Correlation Service Quality of Normal Delivery by Village Midwives and the Satisfaction in Luwu District South Sulawesi." Jurnal Manajemen Kesehatan Indonesia 02(01): 52-58. https://media.neliti.com/media/publications/112371 -ID-none.pdf.

Kemenkes RI. 2020a. kemenkes RI Petunjuk Teknis Pelayanan Puskesmas Pada Masa Pandemi Covid-19. https://covid19.kemkes.go.id/protokolCovid-19/petunjuk-teknis-pelayanan-puskesmaspada-masa-pandemi-Covid-19/\#.X6z9Be77TIU.

Kemenkes RI. 2020b. kemenkes RI Petunjuk Teknis Pelayanan Puskesmas Pada Masa Pandemi Covid-19.

Kementerian Kesehatan RI. Direktorat Jenderal Pelayanan Kesehatan. 2020. Petunjuk Teknis Pelayanan Kesehatan Di Klinik Pada Masa Adaptasi Kebiasaan Baru. Jakarta: Kementerian Kesehatan RI. 2020.

Lexy J. Moleong, Dr. M.A. 2019. "Moleong, Lexi J, 2014. "Metodologi Penelitian Kualitatif Edisi Revisi". Bandung: Remaja Rosdakarya." PT. Remaja Rosda Karya.

Oktarina, Mika. 2016. Buku Ajar Asuhan Kebidanan Dan Bayi Baru Lahir. Yogyakarta: Deepublish.

PP POGI. 2020. "Rekomendasi Penanganan Infeksi Virus Corona (Covid-19)." Maret.

Wahyuni, Sri. 2018. "Karakteristik Bidan dan Kualitas Pelayanan Persalinan di Puskesmas PONED Kabupaten Aceh Besar." JUKEMA 4(1): 282-86. 